\title{
Relationship between valve activity, microalgae concentration in the water and toxin accumulation in the digestive gland of the Pacific oyster Crassostrea gigas exposed to Alexandrium minutum
}

\author{
Hansy Haberkorn ${ }^{\mathbf{a}}$, Damien $\operatorname{Tran}^{\mathbf{b}}$, Jean-Charles Massabuau ${ }^{\mathbf{b}}$, Pierre Ciret $^{\mathbf{b}}$, Véronique Savar ${ }^{\mathbf{c}}$ and \\ Philippe Soudant ${ }^{a, *}$
}

\begin{abstract}
${ }^{a}$ Laboratoire des Sciences de l'Environnement Marin, Institut Universitaire Européen de la Mer, Université de Bretagne Occidentale, Place Copernic, Technopôle Brest-Iroise, 29280 Plouzané, France

${ }^{\mathrm{b}}$ Université Bordeaux 1, CNRS, UMR 5805 EPOC, Place du Dr Peyneau, 33120, Arcachon, France

${ }^{\mathrm{c}}$ IFREMER Centre de Nantes, Laboratoire Phycotoxines, BP 21105, 44311 Nantes, France
\end{abstract}

*: Corresponding author : Philippe Soudant, email address : philippe.soudant@univ-brest.fr

\begin{abstract}
:
The complexity of the relationships between Alexandrium minutum (A.m.) concentration in the water $\left([A . m .]_{\mathrm{w}}\right)$, Paralytic Shellfish Poisoning contamination in the digestive gland ([PSP $]_{\mathrm{dg}}$ ) and valve behavior was explored in oysters Crassostrea gigas. Two experiments were conducted, during which oysters' valve behaviour were analyzed. Oysters, first acclimated for 10-days with the non harmful microalgae Heterocapsa triquetra (H.t.), were exposed to four microalgae mixtures at constant total concentrations of $10 \times 10^{3}$ cells ml ${ }^{-1}$ (experiment- 1 ) and $5 \times 10^{3}$ cells mll $^{-1}$ (experiment-2): $100 \%$ A.m.; $50 \%$ A.m. $-50 \%$ H.t.; $25 \%$ A.m. $-75 \%$ H.t.; $100 \%$ H.t. At the end of experiment-2, [PSP] dg were measured.
\end{abstract}

At $10 \times 10^{3}$ cells $\mathrm{ml}^{-1}$, the microalgal ingestion decreased $(p<0.05)$ with increasing $[A . m .]_{w}$ but not at $5 \times 10^{3}$ cells $\mathrm{ml}^{-1}(p>0.05)$. The frequency of microclosures specifically increased with $[\text { A.m. }]_{\mathrm{w}}$ $(p<0.05)$ and the opening duration with $[\mathrm{PSP}]_{\mathrm{dg}}(p<0.0001)$. Oysters exhibiting the maximum increase in opening duration also exhibited the highest $[P S P]_{\mathrm{dg}}$. The results are discussed in terms of oyster physiology and origin of the behavioral response.

Highlights : Evaluation of behavioural responses of the Pacific oyster $C$. gigas to A. minutum exposure. Are behavioural changes related to concentration of harmful microalgae in water and/or to toxin concentration in oyster digestive gland? A dose-response relationship between the frequency of micro-closures and the concentration of $A$. minutum in the ambient water. $>\mathrm{A}$ doseresponse relationship between opening-duration and the PSP concentration in the digestive gland. Analysis at the individual level suggest that oysters exhibiting different sensitivity to PSPs exist within an oyster stock.

Keywords: Harmful algae; Oysters; Behavioral responses; Algae concentration; Toxin accumulation 


\section{Introduction}

Recent studies have tested modification of shell valve activity in bivalves following harmful microalgal exposure (Nagai et al., 2006; Basti et al., 2009; Tran et al., 2010). The scallop Pinctada fucata exposed to Heterocapsa circularisquama showed an increased frequency of valve adductions or microclosures (Nagai et al., 2006). Similarly, Ruditapes philippinarum increased the frequency of valve adductions and decreased amplitude of valve openings upon exposure to $H$. circularisquama (Basti et al., 2009). In oysters, Crassostrea gigas, exposed to Alexandrium minutum, Tran et al. (2010) also described an increased frequency of microclosures as well as an increase in valve-opening duration. This increased interest in behavioral responses has two major aims: to improve our understanding of the physiological impact of harmful microalgae on bivalve physiology and ecology; to test the putative interest of behavioral change to detect the presence of harmful microalgae or to monitor depuration processes in the field and oyster farms. However, much remains to explore, both in the lab and in the field. The aim of the present study was to gain more insights into the relationship between C. gigas behavior, characterized by shell valve activity, concentration of the harmful microalgae A. minutum in the ambient water and accumulation of PSPs in the digestive gland.

Among harmful microalgae, Alexandrium species are known to produce Paralytic Shellfish Toxins (PSPs). Several commercial bivalve species, such as oysters and mussels, accumulate PSPs by feeding on phytoplanktonic PSP producers (Oshima et al., 1990; Bricelj and Shumway, 1998). PSP accumulation and detoxification kinetics, as well as biotransformation of the toxins, were reviewed in Bricelj and Shumway (1998) and have been well documented for the oyster, Crassostrea gigas, exposed to Alexandrium minutum or A. catenella (Lassus et al., 2005, 2007; Guéguen et al., 2008).

Beyond behavioral studies on valve activity, authors have mainly focused on bivalve feeding and/or digestive responses (Bardouil et al., 1993; Wildish et al., 1998; Li et al., 2001; Bougrier et al., 2003; Lassus et al., 2004; Navarro et al., 2008; Fernández-Reiriz et al., 2008). In the oyster, C. gigas (Bardouil et al., 1993; Wildish et al., 1998; Lassus et al., 2004) and mussel, Mytilus chilensis, (Navarro et al., 2008) an inhibition of feeding activity was reported when animals were exposed to harmful Alexandrium species. In M. chilensis exposed to A. catenella, the inhibition appeared to be reversible after a few days, even though exposure continued, suggesting that mussels can acclimate to feeding on toxic microalgae (Navarro et al., 2008). 
Relationships between the accumulation potential of different bivalve species for PSPs and

69 the ingestion and absorption rates were described by Bricelj et al. (1990) and Bricelj and Shumway (1998). These studies demonstrated an inverse relationship between sensitivity to toxin and potential toxin accumulation. For example, the oyster C. virginica, with high nerve sensitivity to PSPs, potentially accumulates fewer toxins by decreasing ingestion and absorption rates (Bricelj and Shumway, 1998). On the contrary, the mussel Mytilus edulis, which has a low nerve sensitivity to PSPs, accumulates a higher amount of toxins. Another level of complexity has been discussed by Lassus et al. (2000) at the intra-populational level. In C. gigas exposed to A. minutum, they suggested that the variability of contamination status could be related to inter-individual differences in valve and/or clearance activities. This interindividual variability was used by Bougrier et al. (2003) to investigate the relationship between PSP content and clearance rates of C. gigas exposed to A. minutum.

The objective of this work was to go further to the previous study performed by Tran et al., (2010) by i) exposing oysters to different concentrations of A. minutum and ii) measuring PSP concentrations in oyster digestive glands. This allows to evaluate if behavioral responses of the Pacific oyster $C$. gigas are related to the presence and concentration of harmful microalgae in water and/or to toxin concentration in their digestive gland. This is part of a more general work in which the impact of toxic micro-algae on bivalves physiology and the underlying mechanisms explaining behavior variability in the field are studied (Schmitt et al. 2011; Tran et al., 2011). 
Materials and methods

89

\section{Oyster characteristics}

Two experiments were carried out at two different periods, in November-December (Experiment 1) and January-February (Experiment 2), with Pacific oysters, Crassostrea gigas at the University of Brest. Oysters were obtained from a shellfish farmer in the bay of Brest (France). Two homogenous groups of oysters ( $\mathrm{n}=32$ per experiment) were chosen a priori according to the shell length (75 mm shell length, $40 \pm 1 \mathrm{~g}$ total weight). No death was observed during the experiments.

\section{Microalgal cultures}

The dinoflagellate Alexandrium minutum (Halim, strain AM89BM) was grown in 10liter batch cultures using autoclaved seawater filtered to $1 \mu \mathrm{m}$ and supplemented with L1 enrichment (Guillard and Hargraves, 1993). Cultures were maintained at $16 \pm 1^{\circ} \mathrm{C}$ and 100 umol photon. $\mathrm{m}^{-2} . \mathrm{s}^{-1}$, with a dark:light cycle of 12:12h. A. minutum was harvested after 12 days, while still in the exponential growth phase under our conditions. At this age, this strain produced $1.3 \pm 0.1 \mathrm{pg}$ eq. STX per cell, as measured by the method of Oshima (1995).

The dinoflagellate Heterocapsa triquetra (strain HT99PZ - Ehrenberg, 1840) was grown in $10 \mathrm{~L}$ batch cultures in autoclaved, $1 \mu \mathrm{m}$-filtered seawater enriched with $\mathrm{L} 1$ nutrients. Cultures were maintained for 5 days at $16 \pm 1^{\circ} \mathrm{C}$ and $100 \mu \mathrm{mol}$ photon $\mathrm{m}^{-2} \mathrm{~s}^{-1}$, with a dark:light cycle of 12:12h.

\section{Experimental procedure for oyster exposure}

The non-toxic dinoflagellate $H$. triquetra was chosen as a control because of its similarity to A. minutum, in terms of size and shape characteristics: $H$. triquetra cell size (19$28 \mu \mathrm{m})$ is similar to A. minutum cell size (23-29 $\mu \mathrm{m})$. Importantly, A. minutum and $H$. triquetra have different green auto-fluorescence characteristics which allow their individual quantification in mixtures.

The experiments were conducted in an isolated room with minimal human activity to limit inadvertent stimulation of oysters. Experimental tanks were installed on antivibrating benches to minimize any external disturbance that could interfere with the behavior of the oysters. Experiments were carried out with a photoperiod of $12 \mathrm{~h}$ light / $12 \mathrm{~h}$ dark and seawater was maintained at a temperature of $16 \pm 1^{\circ} \mathrm{C}$. Prior to the experiments, oysters were 
distributed randomly into eight 10-liter tanks (four tests and four controls), with four oysters per tank. Oysters were maintained in the same tanks during the entire experiment to avoid behavioral disturbance from handling. Each tank was individually supplied with cultured microalgal suspensions using a multichannel peristaltic pump. Central air-lifts were used to homogenize microalgal concentration and water in the tanks. Present experiments were performed at two different total microalgae concentrations $\left(10 \cdot 10^{3}\right.$ cells $\cdot \mathrm{ml}^{-1}$ and $5 \cdot 10^{3}$ cells $\cdot \mathrm{ml}^{-1}$ ), which correspond with bloom concentrations observed on French coast (Belin and Raffin, 1998).

Experiment 1. As a first step to characterize a relationship between concentration of $A$. minutum in water and behavior of oysters, oysters were exposed to four different microalgal mixtures, at an identical total concentration of microalgae of $10 \cdot 10^{3}$ cells. $\mathrm{ml}^{-1}$. Three different phases were considered: acclimation period (Acc.; $t_{0}-t_{10}$ ), exposure period (Exp.; $t_{11}-t_{12}$ ) and recovery period (Rec.; $\mathrm{t}_{13}-\mathrm{t}_{18}$ ). During the 10-day acclimation period, each tank received

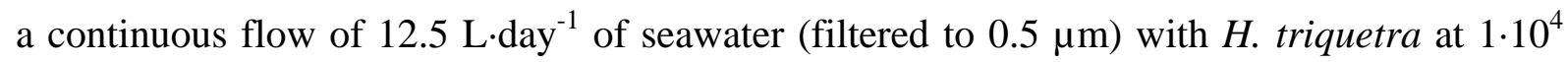
cells $\cdot \mathrm{ml}^{-1}$. Following the acclimation period, four supply tanks were used to distribute microalgal suspensions into the respective, replicated experimental tanks (two tanks per condition). Supply tanks were prepared with each of four microalgal mixtures: i) $100 \%$ A. minutum $\left(1 \cdot 10^{4}\right.$ cells $\left.\cdot \mathrm{ml}^{-1}\right)$, ii) $50 \%$ A. minutum- $50 \% \mathrm{H}$. triquetra $\left(5 \cdot 10^{3}\right.$ cells $\cdot \mathrm{ml}^{-1}$ of $A$. minutum and $5 \cdot 10^{3}$ cells $\cdot \mathrm{ml}^{-1}$ of $H$. triquetra), iii) $25 \%$ A. minutum- $75 \%$ H. triquetra $\left(2.5 \cdot 10^{3}\right.$ cells $\cdot \mathrm{ml}^{-1}$ of $A$. minutum and $7.5 \cdot 10^{3}$ cells $\cdot \mathrm{ml}^{-1}$ of $H$. triquetra) and iv) $100 \%$ H. triquetra

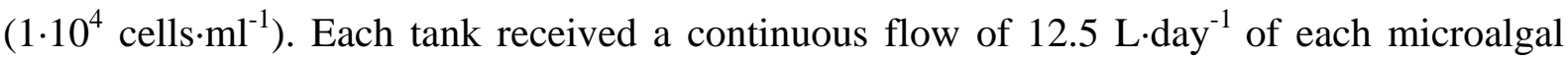
treatment. The exposure period continued for two days, followed by five days of recovery

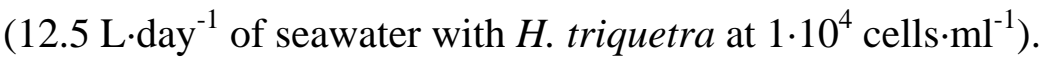

Experiment 2. To test the possible relationship between behavior and toxin accumulation, toxin contents in the digestive glands of the oysters were determined at the end of the exposure period. Two different phases were considered: acclimation period (Acc., $\mathrm{t}_{0}-$ $t_{10}$ ) and a 5-days exposure period (Exp., $t_{11}-t_{15}$ ). During the 10-day acclimation period, each tank received a continuous flow of 12.5 L.day ${ }^{-1}\left(8.7 \mathrm{ml} \mathrm{min}^{-1}\right.$ ) of seawater (filtered to $0.5 \mu \mathrm{m}$ ) with $H$. triquetra at $5.10^{3}$ cells.ml ${ }^{-1}$. Following the acclimation period, four microalgal supply tanks were used to distribute microalgal suspensions into the respective, replicated experimental tanks (two tanks per condition). Supply tanks were prepared with each of four microalgal mixtures: i) $100 \%$ A. minutum $\left(5 \cdot 10^{3}\right.$ cells.ml $\left.^{-1}\right)$, ii) $50 \%$ A. minutum- $50 \% \mathrm{H}$. triquetra $\left(2.5 \cdot 10^{3}\right.$ cells.ml ${ }^{-1}$ of $A$. minutum and $2.5 \cdot 10^{3}$ cells. $\mathrm{ml}^{-1}$ of $H$. triquetra), iii) $25 \% A$. 
minutum- $75 \%$ H. triquetra $\left(1.25 \cdot 10^{3}\right.$ cells. $\mathrm{ml}^{-1}$ of $A$. minutum and $3.75 \cdot 10^{3}$ cells.ml ${ }^{-1}$ of $H$. triquetra) and iv) $100 \% \mathrm{H}$. triquetra $\left(5 \cdot 10^{3}\right.$ cells. $\left.\mathrm{ml}^{-1}\right)$. Each tank received a continuous flow of $12.5{\mathrm{~L} . \mathrm{day}^{-1}}^{-1}$ of each microalgal treatment. At the end of the exposure period, the digestive glands of individual oysters were dissected, weighed, frozen immediately in liquid nitrogen, and stored at $-80^{\circ} \mathrm{C}$ until analysis. Later, digestive glands were ground with a "Dangoumeau" homogenizer into liquid nitrogen and this sample was used to measure toxin content.

\section{C. gigas valve-activity measurement}

To evaluate the effect of $A$. minutum on the valve behavior of $C$. gigas throughout the experiment, we recorded the valve activity continuously with a laboratory made valvometer. The oysters were equipped (at $\mathrm{t}_{0}$ ) with light weight $(\approx 1 \mathrm{~g}$ ) electromagnetic electrodes glued onto both shells. The electrodes allow the oysters to move their valves without constraint. More details are described in Tran et al. (2003) and Chambon et al. (2007), as well as data about the required adaptation periods before experimental set-up (Tran et al., 2003). The record of valve activity started at $\mathrm{t}_{0}$.

The free ends of the electrodes were connected to an electronic apparatus composed mainly of a multiplexer that switched the current every 300 msec from one pair of electrodes to another, and a computer driving the apparatus via a data acquisition card (LAB PC 1200; National Instruments, Austin, TX, USA), using LabView 8.0 software (National Instruments).

\section{Phytoplankton sampling}

During exposure periods, 1-ml water samples were collected from supply tanks, both at the input and within the oyster tanks, in order to determine microalgal cell densities. Samples were collected and fixed in 3\% formaldehyde (final concentration) at 1, 3, 5, 6, 7, 23, 24 and 27h30 after the beginning of the exposure for experiment 1 and at 1, 15, 17, 20, 24, 26, 40, 48 and 64 h for experiment 2. Samples were analyzed by flow cytometry within one day of sampling.

\section{Measurements of dinoflagellate cell densities by flow cytometry}

Measurements of dinoflagellate cell concentrations were performed using a FACScalibur (BD Biosciences, San Jose, CA USA) flow cytometer (FCM) equipped with a $488 \mathrm{~nm}$ argon laser. Threshold was set to FL3 (red fluorescence, 550-600 nm) to detect only chlorophyll-containing cells. Settings were adjusted to visualize dinoflagellate cells on two cytograms with i) Forward Scatter (FSC, related to cell size) vs Side Scatter (SSC, related to 
189 cell internal complexity), and ii) red auto-fluorescence (FL3) vs green auto-fluorescence 190 (FL1) as parameters. Cells of A. minutum and $H$. triquetra possess similar FSC and SSC 191 characteristics, but $A$. minutum has higher FL1 in comparison to H. triquetra, making the two cells distinguishable in a mixed suspension. Cell densities were estimated from flow-rate measurement of the flow-cytometer (Marie et al., 1999), as all samples were run for 1 min. Results were expressed as number of cells per ml.

\section{Toxin content}

Digestive gland (ground, $0.5 \mathrm{~g}$ ) was extracted in $1 \mathrm{ml}$ of $0.1 \mathrm{~N} \mathrm{HCl}(2 \mathrm{v} / \mathrm{w})$ at $4^{\circ} \mathrm{C}$. After centrifugation $\left(3,000 \times \mathrm{g}, 15 \mathrm{~min}, 4^{\circ} \mathrm{C}\right), \mathrm{pH}$ of extracts was adjusted to 3.0 with $12 \mathrm{~N}$ $\mathrm{HCl}$. After half-dilution, supernatants were ultra-filtered (20 kDa, Sartorius Centrisart) and stored at $4^{\circ} \mathrm{C}$ until analysis. PSPs were analyzed by ion-pairing, high-performance liquid chromatography (IP-HPLC) according to the method of Oshima (1995). The molar concentration ( $\mu \mathrm{mol} \mathrm{l}^{-1}$ ) was converted into $\mu \mathrm{g}$ STX equiv. $100 \mathrm{~g}^{-1}$ of digestive gland by using the conversion factors of Oshima (1995). Results were expressed in $\mu$ g STX equiv. $100 \mathrm{~g}^{-1}$ of digestive gland wet weight.

\section{Statistical analysis}

Results are expressed as mean \pm confidence interval (CI). Differences between variables before and during A. minutum exposure were determined using the T-test, after checking assumptions (normality and homoscedasticity of the error term).

Homogenous groups were identified using multiple range comparison tests (ANOVA) to determine which means were significantly different from which others and Fisher's least significant difference (LSD) procedure discriminated among the means. On graphics, the same letter was used for means which were not statistically different. A statistical regression was used to correlate toxin content and behavioral variables. The fit between predicted and measured values was tested statistically using ANOVA. For all statistical results, a probability of $p<0.05$ was considered significant. Statistical analyses were performed using Statgraphics Plus (Manugistics, Inc, Rockville, MD, USA). 
Under acclimation conditions, in tanks fed with $10 \cdot 10^{3}$ cells.ml ${ }^{-1}$ without A. minutum, oysters consumed $92.5 \pm 4.6 \%$ of the microalgae supplied in the tanks (Fig. 1A). This percentage decreased with increasing ratio of $A$. minutum added $(79.5 \pm 9.9 \%$ at $25 \%$ A.m./75 $\%$ H.t.; $81.7 \pm 6.8 \%$ at $50 \%$ A.m./50 \% H.t. and $48.8 \pm 12.6 \%$ at $100 \%$ A.m./0 \% H.t.). On the contrary, when animals were fed with half the concentration of microalgae, $5 \cdot 10^{3}$ cells. $\mathrm{ml}^{-}$ ${ }^{1}$, all microalgae were consumed, independent of the Alexandrium concentration in the input water (Fig. 1B). In all conditions, no microalgal sedimentation was observed and no noticeable amount of feces and/or pseudofeces were found in the tanks. Similar decreases of both microalgae in the mixture (A. minutum and $H$. triquetra) were measured showing that $C$. gigas fed equally on both species.

Figure 2 illustrates the similarity and replicability of the present experimental conditions: no statistical difference was observed between any of the 8 tanks that were running in parallel, during both acclimation conditions $(p>0.05)$ or during the second day of recovery $(p>0.05)$. Similarly, paired comparison between the two series of replicate did not reveal statistical difference. This allowed evidencing dose-response relationship between behavioral responses and water concentration of A. minutum in C. gigas. During the 2-day exposure period, the oysters exhibited significantly more valve micro-closures in the presence of $A$. minutum (see inserts in Fig. 2). The number of valve micro-closures was 3.5 times higher in the presence of $100 \%$ A. minutum, 3.1 times higher at $50 \%$ and 1.9 times higher at $25 \%$, in relation to the acclimation period of the oysters in the same tanks. It is only following the exposure to $25 \%$ A. minutum that valve micro-closure was not significantly different from the acclimation period and the 2 days of recovery. Figure 3 presents the mean values in the above series of replicates (Experiment 1) and demonstrates how the number of micro-closures statistically increased at higher A. minutum concentrations. During recovery, it significantly decreased towards acclimation values (see inserts in Fig. 2).

Figure 4A and $\mathrm{C}$ shows the absence of a relationship between PSP concentration in the digestive gland and concentration of $A$. minutum in the water supplying the tanks ( $p>0.05)$ while figure 4B and $\mathrm{D}$ (data analysis either performed per oyster, 4B, or per tank, 4D) shows a positive correlation between toxin accumulation and daily opening duration. Figure 5A and 
251 prior exposure (mean value during the 5 last day acclimation period, $p>0.05$ ). This is 252 coherent with the absence of significant difference within the whole set of reference and 253 recovery conditions (low acclimation variability). This low variability completely vanished 254 under exposure conditions. The more "responsive” animals (Fig 5B) or tanks (Fig. 5D), 255 identified as those showing the most dramatic differences in daily opening duration between 256 acclimation and exposure phases, were those exhibiting the highest accumulation of PSP in 257 their digestive gland (Fig. 5B; $p<0.0001, \mathrm{R}^{2}=0.67$ ). A comparison between the opening 258 duration between the acclimation period (Fig. 5A, per individual, or 5C, per tank) and the 259 exposure period (Fig. 4B, per individual, or 4D, per tank) shows a greatly increased 260 variability in the presence of $A$. minutum. Under acclimation conditions the min-max values 261 were $18-40 \%$ of opening duration while they were $19-85 \%$ with A. minutum. 


\section{Discussion}

263

264

265

266

267

268

269

270

271

272

273

274

275

276

277

278

279

280

281

282

283

284

285

286

287

288

289

290

291

292

293

294

The objective of this work was to evaluate if behavioral responses of the Pacific oyster C. gigas are related to the presence and concentration of harmful microalgae in water and/or to toxin concentration in their digestive gland. A dose-response relationship was observed between the frequency of micro-closures and the concentration of A. minutum in the ambient water but no dose-response relationship between micro-closures and the PSP concentration in the digestive gland. On the contrary, opening-duration showed a dose-response relationship to the PSP concentration in the digestive gland but not to the concentration of $A$. minutum in the water. In addition, data showed that the inter-individual variability of opening-duration increased during exposure in comparison to the acclimation period. Oysters exhibiting the largest increase in opening duration were those with the largest toxin content in the digestive gland. There was no relationship between acclimation and intensity of response during exposure as regard to the opening duration.

Behavioral changes versus total microalgae concentrations

Present experiments were performed at two different total microalgal concentrations $\left(10 \cdot 10^{3}\right.$ cells $\cdot \mathrm{ml}^{-1}$ and $5 \cdot 10^{3}$ cells $\left.\cdot \mathrm{ml}^{-1}\right)$, with the aim to experimentally manipulate oyster feeding activity. Analysis of experiment $1\left(10 \cdot 10^{3}\right.$ cells $\left.\cdot \mathrm{ml}^{-1}\right)$ suggested that feeding activity slightly decrease with increasing proportion of A. minutum in the mixture. Such decreases of filtration rate were previously reported in C. gigas exposed to the toxic dinoflagellate Alexandrium tamarense (Bardouil et al., 1993) and A. minutum (Lassus et al., 1999). Lassus et al. (2004) also reported an inhibition effect at $10 \cdot 10^{3}$ cells $\cdot \mathrm{ml}^{-1}$ in $C$. gigas fed with $A$. minutum. Present results showed that feeding was partly inhibited at $10 \cdot 10^{3}$ of $A$. minutum but not at $5 \cdot 10^{3}$ cells $\cdot \mathrm{ml}^{-1}$. This could be the result of a balance between feeding requirements and a protective response.

Impact of the A. minutum concentration in the water

Among the variables measured to describe oyster behavior, the frequency of valve micro-closures was positively correlated to the percentage of $A$. minutum added, at a constant total microalgae concentration. Tran et al., (2010), previously suggested that such behavior could be related to an avoidance response to minimize contact with harmful cells and/or effects of toxins released during digestion of A. minutum cells. This behavior could also help the animal to rapidly test the ambient water content (back and forth water movements across 
the mantle border and in the palleal cavity). The present report demonstrates that, in the present experimental conditions, this was associated to the concentration of A. minitum in the water and not to the PSP accumulation in the animal. Similar increases of valve microclosures, correlated with increased concentrations of harmful microalgae, have been observed by Basti et al. (2009) in $R$. philippinarum exposed to Heterocapsa circularisquama. The

300 absence of PSP toxin production by $H$. circularisquama demonstrated that the presence of this toxin is not a prerequisite to induce an increase of micro-closures.

\section{Relationship with toxin concentration in the digestive gland}

In C. gigas, 90 \% of PSP toxins are accumulate in the digestive gland (Guéguen et al., 2008; Lassus et al., 2007) explaining why PSPs were only analyzed in this organ. Present data showed that valve opening duration was dose-related to the concentration of PSP in the digestive gland. A comparison with previous reports shows that a positive relationship between feeding time and tissue PSP concentration was reported in C. gigas and Pecten maximus exposed to A. minutum (Bougrier et al., 2003). In this study, feeding time activity was indirectly evaluated by measuring the decrease in toxic cell density at the outlets of experimental tanks and biodeposit production. Although mean oyster responses to microalgal treatments and toxin accumulation are well documented in the literature, it is known that response intensity at the individual level is quite variable, from no change at all to very important and dramatic changes (see for examples Bricelj and Shumway, 1998; Lassus et al., 2007). This is also similar to PSP accumulation in C. gigas: numerous animals remained in the low range of the global distribution data while a minority accumulated the largest amounts (present report; Fig. 6 in Lassus et al., 2007). The present report demonstrates that this interindividual variability of bioaccumulation was positively correlated to the opening duration during the exposure period (Fig. 4B, 4D) but not before it (Fig. 5A, 5C). Was the presence of larger quantities of PSP in the digestive gland responsible for the longer opening duration during exposure? Or, alternatively, was the longer opening duration, and incidentally a larger clearance value, responsible for a larger toxin bioaccumulation?

The hen and egg problem

One must recall first that with $A$. minutum we are dealing with a paralyzing toxin, that we measured it in the digestive gland following a 5 day exposure period and that its distribution in the whole animal was presumably not time limited. Was the presence of larger quantities of PSP in the digestive gland responsible for the longer opening duration? Among 
the presently known physiological and behavioral alterations induced by PSP, are (i)

330 alterations of action potential transmission by blocking sodium conductance in nerve fibers

331 (Narahashi and Moore, 1968) and (ii) absence of response to mechanical stimulation of the gills and adductor muscle in gaping Crassostrea virginica (Hégaret et al., 2007). In the softshell clam Mya arenaria, Bricelj et al. (2005) reported muscle paralysis induced by paralytic shellfish toxin and in C. gigas, Haberkorn et al. (2010) described important morphological alterations of the adductor muscle. Physiological impacts could explain the larger opening durations. Alternatively, Tran et al. (2010) suggested muscular fibers of gills (Medler and Silverman, 2001) could be targets of PSP toxins. This could lead to a decrease in pumping efficiency in terms of volume of water ventilated per unit of time. Thus, a reduction of filtration efficiency during exposure to A. minutum would be compensated for by longer ventilatory periods in order to fulfill the animal's $\mathrm{O}_{2}$-requirements and/or nutritional needs.

Was the longer opening duration, and a larger filtered volume of water, responsible for a larger toxin bioaccumulation? Feeding behavior was hypothesized by Bricelj and Shumway (1998) to be one of the parameters responsible for inter-individual variation in toxin accumulation. The present results show that in C. gigas there was no relationship between acclimation opening duration and contamination levels (Fig. 5A, 5C) nor between acclimation opening duration and animal reactivity (measured as test - acclimation opening duration) to A. minutum. On the contrary, present results suggest the existence of an inter-individual reactivity that may reflect differences in sensitivity to PSPs or to any other compounds or characteristics associated with A. minutum. In that view, oysters accumulating the largest amounts of toxins could be considered less sensitive in comparison to oysters accumulating fewer toxins. This hypothesis has already been formulated by Bricelj and Shumway (1998) for different bivalve species. Bivalve species possessing low nerve sensitivity to PSP (e.g. $M$. edulis) were found to readily feed on toxic cells and thus accumulate high levels of toxins (Bricelj and Shumway, 1998). In contrast, oysters (e.g. C. virginica) described as PSPsensitive species accumulated less PSP (Bricelj and Shumway, 1998). Differences in toxin accumulation (up to five times), observed between different populations of the same clam species, $M$. arenaria, were related to intra-species variability, in terms of PSP sensitivity. A natural mutation of a single amino acid residue decreases affinity (1,000-fold) of the saxitoxin-binding site in the sodium channel pore. This mutation was found to be responsible for the difference in nerve sensitivity between the two populations of $M$. arenaria exposed to PSP-producing Alexandrium fundyense (Bricelj et al., 2005). Furthermore, the present results underscore the possibility of finding differences in sensitivity to PSPs within an oyster stock 
363 (intra-population). Less-sensitive oysters would open their valves longer and would consume 364 more toxic dinoflagellates. This is of course speculation but opens exciting research directions 365 for the future.

366 To go further in understanding relationships between oysters behavior, toxin 367 accumulation and $A$. minutum concentration in water, it would be interesting to use the same 368 experimental design, but by maintaining constant $A$. minutum concentration during the whole 369 exposure period. To better understand if behavioral changes were because of PSP content, 370 oysters could be exposed to PSP producer $A$. minutum strain and non-PSP producer $A$. 371 minutum strain. 


\section{Acknowledgments}

373

374 We thank Marielle Guéguen and Patrick Lassus, for their advices and technical assistance.

375 This study was carried out with the financial support of the National Research Agency 376 (ANR), "MODECOPHY" project 06SEST23 (2006-2009) and of the Brittany Region, 377 "EPHYTOX" project. We also thank Aquitaine Region and the SME "EUKREA 378 Electromatique” for financial support. 


\section{References}

Bardouil, M., Bohec, M., Cormerais, M., Bougrier, S., Lassus, P., 1993. Experimental study of the effects of a toxic microalgal diet on feeding of the oyster Crassostrea gigas Thunberg. J. Shellfish Res. 12, 417-422.

Basti, L., Nagai, K., Shimasaki, Y., Oshima, Y., Honjo, T., Segawa, S., 2009. Effects of the toxic dinoflagellate Heterocapsa circularisquama on the valve movement behaviour of the Manila clam Ruditapes philippinarum. Aquaculture 291, 41-47.

Belin, C., Raffin, B., 1998. Les espèces phytoplanctoniques toxiques et nuisibles sur le littoral français de 1984 à1995, résultats du REPHY (Réseau de surveillance du phytoplancton et des phycotoxines). REPHY report. Ifremer, France, p. 143.

Bougrier, S., Lassus, P., Bardouil, M., Masselin, P., Truquet, P., 2003. Paralytic shellfish poison accumulation yields and feeding timeactivity in the Pacific oyster (Crassostrea gigas) and king scallop (Pecten maximus). Aquat. Living Resour. 16, 347-352.

Bricelj, V.M., Lee, J.H., Cembella, A.D., Anderson, D.M., 1990. Uptake kinetics of paralytic shellfish toxins from the dinoflagellate Alexandrium fundyense in the mussel Mytilus edulis. Mar. Ecol. Prog. Ser. 63, 177-188.

Bricelj, V.M., Shumway, S.E., 1998. Paralytic shellfish toxins in bivalve molluscs: occurrence, transfer kinetics, and biotransformation. Res. Fish. Sci. 6, 315-383.

Bricelj, V.M., Connell, L., Konoki, K., Mac-Quarrie, S.P., Scheuer, T., Catterall, W.A., Trainer, V.L., 2005. Sodium channel mutation leading to saxitoxin resistance in clams increases risk of PSP. Nature 434, 763-767.

Chambon, C., Legeay, A., Durrieu, G., Gonzalez, P., Ciret, P., Massabuau, J.-C., 2007. Influence of the parasite worm Polydora sp. on the behavior of the oyster Crassostrea gigas: a study of the respiratory impact and associated oxidative stress. Mar. Biol. 152, 329-338.

Fernández-Reiriz, M.J., Navarro, J.M., Contreras, A.M., Labarta, U., 2008. Trophic interactions between the toxic dinoflagellate Alexandrium catenella and Mytilus chilensis: Feeding and digestive behaviour to long-term exposure. Aquat. Toxicol. 87, 245-251.

Guéguen, M., Bardouil, M., Baron, R., Lassus, P., Truquet, P., Massardier, J., Amzil, Z., 2008. Detoxification of Pacific oyster Crassostrea gigas fed on diets of Skeletonema costatum with and without silt, following PSP contamination by Alexandrium minutum. Aquat. Living Resour. 21, 13-20.

Guillard, R.R.L., Hargraves, P.E., 1993. Stichochrysis immobilis is a diatom, not a chrysophyte. Phycologia 32, 234-236.

Haberkorn, H., Lambert, C., Le Goïc, N., Moal, J., Suquet, M., Guéguen, M., Sunila, I., Soudant, P., 2010. Effects of Alexandrium minutum exposure on nutrition-related processes and reproductive output in oysters Crassostrea gigas. Harmful Algae. 9, 427-439.

Hégaret, H., Wikfors, G.H., Soudant, P., Lambert, C., Shumway, S.E., Bérard, J.B., Lassus, P., 2007. Toxic dinoflagellates (Alexandrium fundyense and A. catenella) have little apparent effect on oyster hemocytes. Mar. Biol. 141, 441-447.

Lassus, P., Bardouil, M., Beliaeff, B.,Masselin, P., Naviner, M., Truquet, P., 1999. Effect of a continuous supply of the toxic dinoflagellate Alexandrium minutum Halim on the feeding behavior of the Pacific oyster (Crassostrea gigas Thunberg). J. Shellfish Res. 18, 211-216.

Lassus, P., Bardouil, M., Massselin, P., Naviner, M., Truquet, P., 2000. Comparative efficiencies of different non-toxic microalgal diets in detoxification of PSPcontaminated oysters (Crassostrea gigas Thunberg). J. Nat. Toxins 9, 1-12. 
Lassus, P., Baron, R., Garen, P., Truquet, P., Masselin, P., Bardouil, M., Leguay, D., Amzil, Z., 2004. Paralytic shellfish poison outbreaks in the Penze estuary: Environmental factors affecting toxin uptake in the oyster, Crassostrea gigas. Aquat. Living Resour. 17, 207-214.

Lassus, P., Bardouil, M., Baron, R., Bérard, J.B., Masselin, P., Truquet, P., Pitrat, J.P., 2005. Improving detoxification efficiency of PSP-contaminated oysters (Crassostrea gigas Thunberg). Aquaculture Europe, 3-6.

Lassus, P., Amzil, Z., Baron, R., Séchet, V., Barillé, L., Abadie, E., Bardouil, M., Sibat, M., Truquet, P., Bérard, J.B., Guéguen, M., 2007. Modelling the accumulation of PSP toxins in Thau Lagoon oysters (Crassostrea gigas) from trials using mixed cultures of Alexandrium catenella and Thalassiosira weissflogii. Aquat. Living Resour. 20, 5967.

Li, S.C., Wang, W.X., Hsieh, D., 2001. Feeding and absorption of the toxic dinoflagellate Alexandrium tamarense by two marine bivalves from the South China Sea. Mar. Biol. 139, 617-624.

Li, S.C., Wang, W.X., 2001. Radiotracer studies on the feeding of two marine bivalves on the toxic and nontoxic dinoflagellate Alexandrium tamarense. J. Exp. Mar. Biol. Ecol. 263, 65-75.

Marie, D., Partensky, F., Vaulot, D., Brussaard, C., 1999. Current Protocols in Cytometry, chap. Enumeration of phytoplankton, bacteria, and viruses in marine samples, pp. 11.11.11_11.11.15, New York: John Wiley \& Sons Inc.

Medler, S., Silverman, H., 2001. Muscular alteration of gill geometry in vitro: implications for bivalve pumping processes. Biol. Bull. 200, 77-86.

Nagai, K., Honjo, T., Go, J., Yamashita, H., Oh, S.J., 2006. Detecting the shellfish killer Heterocapsa circularisquama (Dinophyceae) by measuring bivalve valve activity with a Hall element sensor. Aquaculture 255, 395-401.

Narahashi, T., Moore, J.W., 1968. Neuroactive agents and nerve membrane conductances. J. Gen. Physiol. 51, 93-101.

Navarro, J.M., Contreras, A.M., Chaparro, O.R., 2008. Short-term feeding response of the mussel Mytilus chilensis exposed to diets containing the toxic dinoflagellate Alexandrium catenella. Rev. Chil. Hist. Nat. 81, 41-49.

Oshima, Y., Sugino, K., Itakura, H., Hirota, M., Yasumoto, T., 1990. Comparative studies on paralytic shellfish toxin profile of dinoflagellates and bivalves. In: Graneli, E., Sundstrom, B., Edler, L., Anderson, D.M. (eds.) Toxic marine phytoplankton. Elsevier Science Publishing, New York, p. 391-396.

Oshima, Y., 1995. Postcolumn derivatization liquid chromatographic method for paralytic shellfish toxins. J AOAC Int. 78, 528-532.

Schmitt, F.G., De Rosa, M., Durrieu, G., Sow, M., Tran, D., P., Ciret, P., Massabuau, J.C., 2011. Statistical study of bivalve high frequency microclosing behavior: scaling properties and shot noise analysis. Int. J. Bifurcat. Chaos. in press

Tran, D., Ciret, P., Ciutat, A., Durrieu, G., Massabuau, J.C., 2003. Estimation of potential and limits of bivalve closure response to detect contaminants: application to cadmium. Envir. Tox. Chem. 22, 914-920.

Tran, D., Haberkorn, H., Soudant, P., Ciret, P., Massabuau, J.C., 2010. Behavioral responses of Crassostrea gigas exposed to the harmful algae Alexandrium minutum. Aquacutlure. 298, 338-345.

Tran, D., Nadau, A., Durrieu, G., Ciret, P., Parisot, J.P., Massabuau, J.C., 2011. Field chronobiology in a molluscan bivalve: how the moon and sun cycles interact to drive oyster activity rhythms. Chronobiol. Int. (in press)

Wildish, D., Lassus, P., Martin, J., Saulnier, A., Bardouil, M., 1998. Effect of the PSP-causing 
dinoflagellate, Alexandrium sp., on the initial feeding response of Crassostrea gigas.

480

Aquat. Living Resour. 11, 35-43.

481 


\section{Figure captions}

482

483

484

485

486

487

488

489

490

491

492

493

494

495

496

497

498

499

500

501

502

503

504

505

506

507

508

509

510

511

512

513
Fig. 1: Total microalgae concentrations measured in the inflow (black bars) and outflow (grey bars) of experimental tanks, for different experimental conditions, during experiments 1 (A) and 2 (B). Mean \pm confidence interval, $n=8$ samples per condition. Letters ( $\mathrm{a}, \mathrm{b}, \mathrm{c}$ and $\mathrm{d}$ ) represent 4 homogenous groups, identified using multiple range comparison tests whenever ANOVA was significant.

Fig. 2: Experiment 1. Dose-response behavior at various concentrations of $A$. minutum in the ambient water. Frequency of micro-closures, expressed in number per hour, in 8 different experimental tanks running in parallel (4 conditions and 2 replicates). Acc. (48 $\mathrm{h}$ of acclimation), Exp. (48 h of exposure) and Rec. (48 h of recovery). Mean \pm confidence interval, $\mathrm{n}=4$ oysters per tank. * significantly different from Acc., ** significantly different from Exp.

Fig. 3. Experiment 1, mean dose-response behavior. Mean frequency of valve micro-closures in oysters $C$. gigas exposed to different $A$. minutum concentrations in 8 different experimental tanks running in parallel (4 conditions and 2 replicates). Mean \pm confidence interval, $n=4$ oysters per tank. Letters (a, b, c and d) represent 4 homogenous groups, identified using multiple range comparison tests whenever ANOVA was significant.

Fig. 4: Experiment 2, change of toxin contents in oysters, expressed as $\mu$ g STX eq. $100 \mathrm{~g}^{-1}$ digestive gland wet weight (DGWW), either per individual oyster (A, B) or experimental tank (C, D): toxin content as a function of (A and C) concentration of $A$. minutum in the inflow water and of (B and D) valve-opening duration. Five days of exposure duration; $A, B, n=24$ oysters; $\mathrm{C}, \mathrm{D}, \mathrm{n}=6$ tanks, mean \pm confidence interval.

Fig. 5: Experiment 2, change of toxin contents in oysters, expressed as $\mu$ g STX eq. $100 \mathrm{~g}^{-1}$ digestive gland wet weight (DGWW), either per individual oyster (A, B) or experimental tank $(\mathrm{C}, \mathrm{D})$ : toxin content as a function of (A and $\mathrm{C}$ ) opening duration during acclimation period and of (B and D) difference of valve-opening duration between Exposure and Acclimation period (Exp - Acc). Five days of exposure duration; A, B, $n=24$ oysters; C, D, $n=6$ tanks, mean \pm confidence interval. 


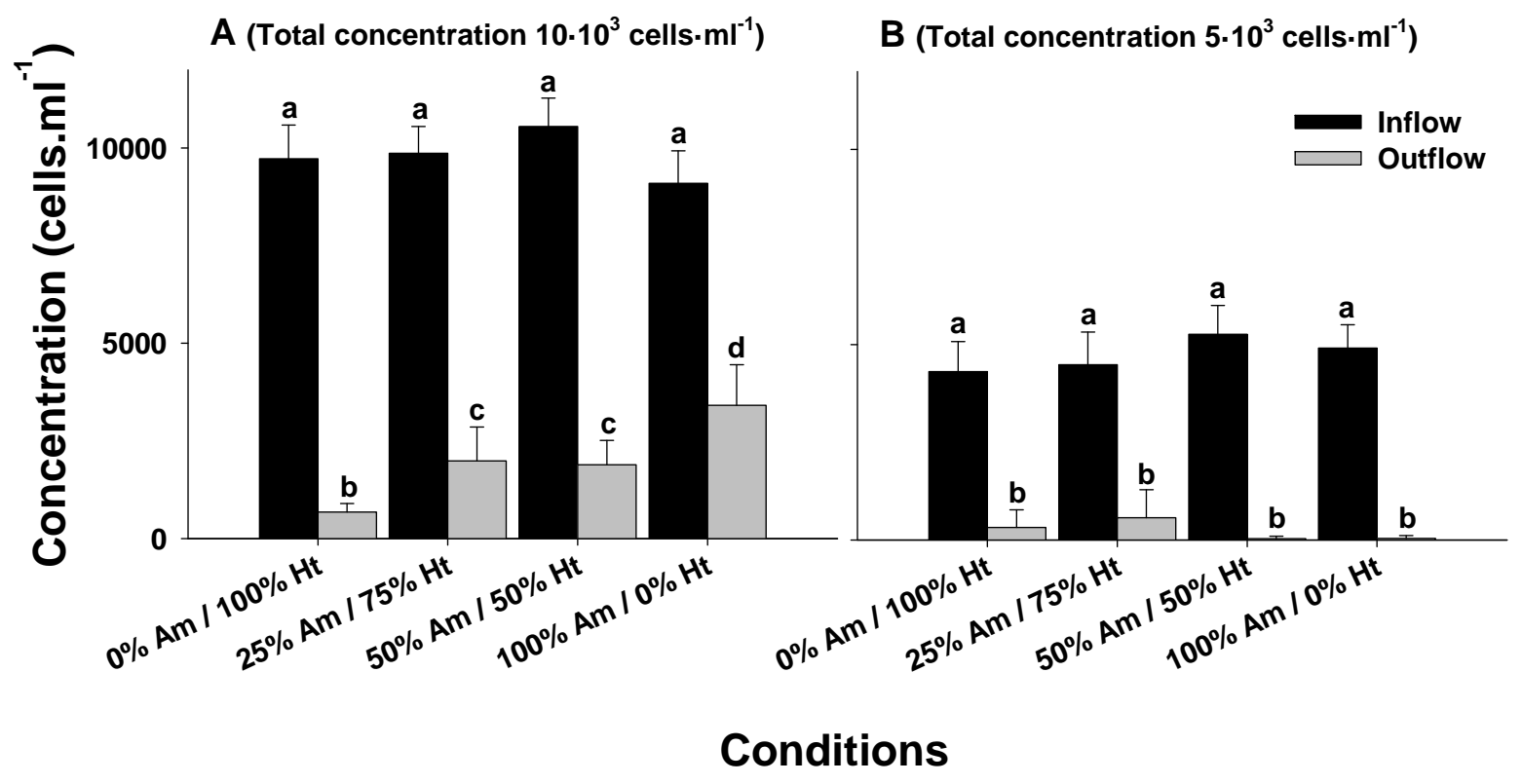

Figure 1 


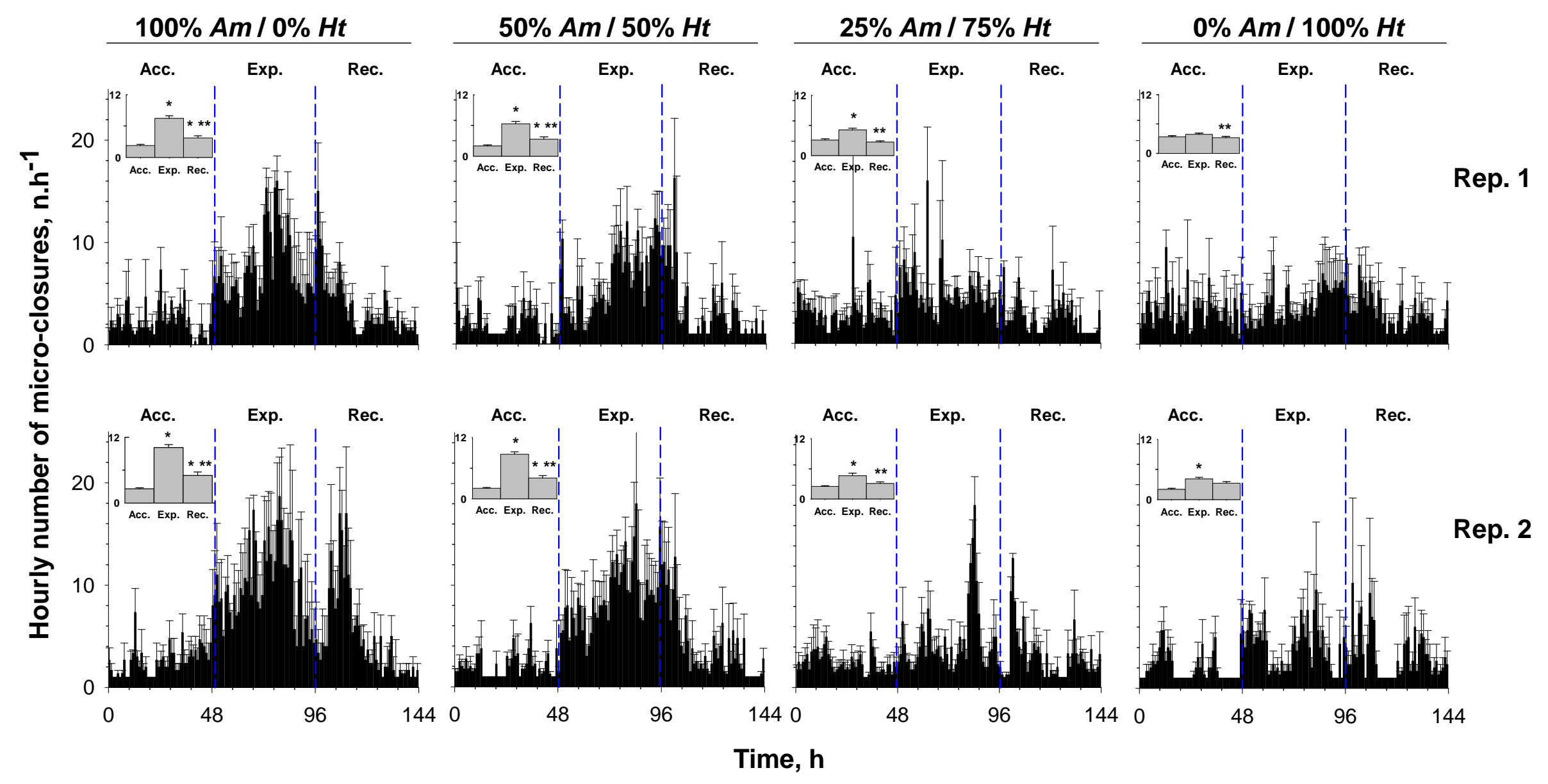

Figure 2 


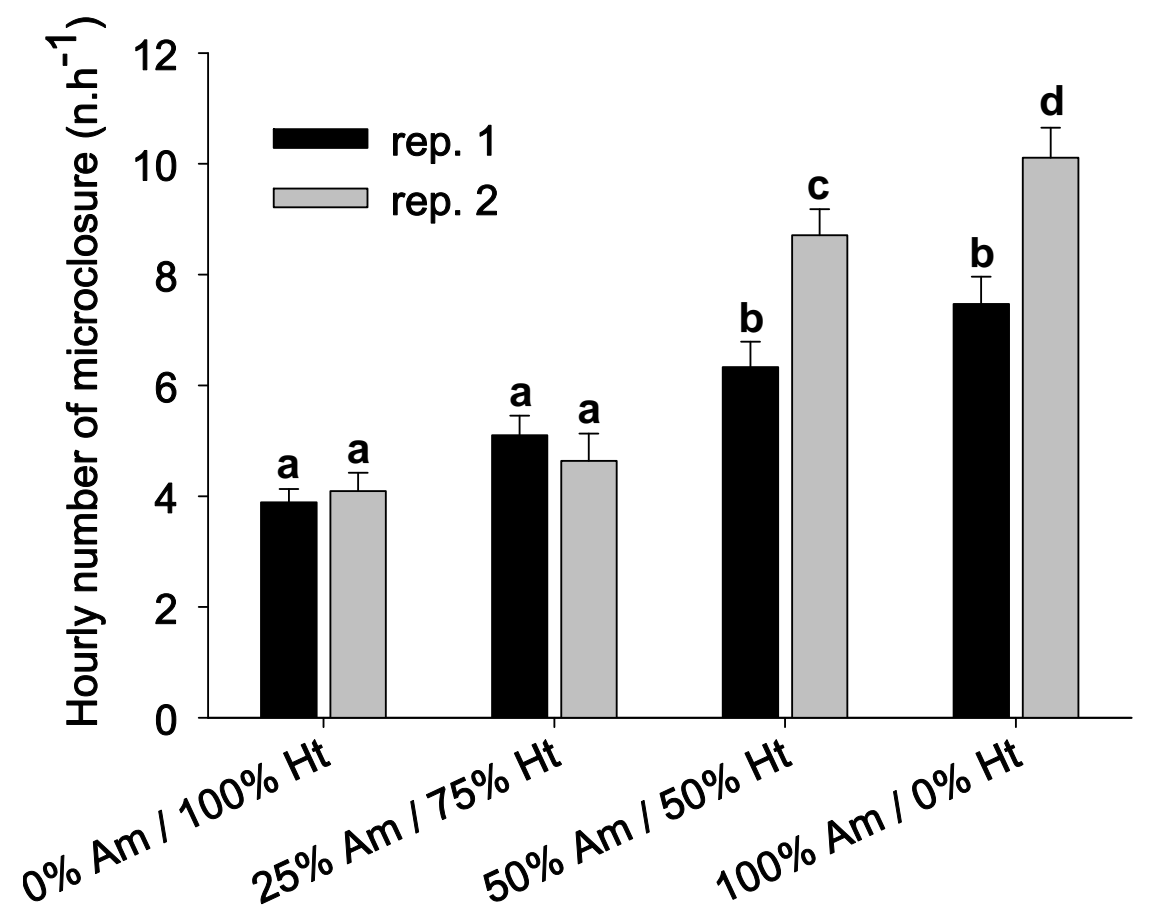

Figure 3 


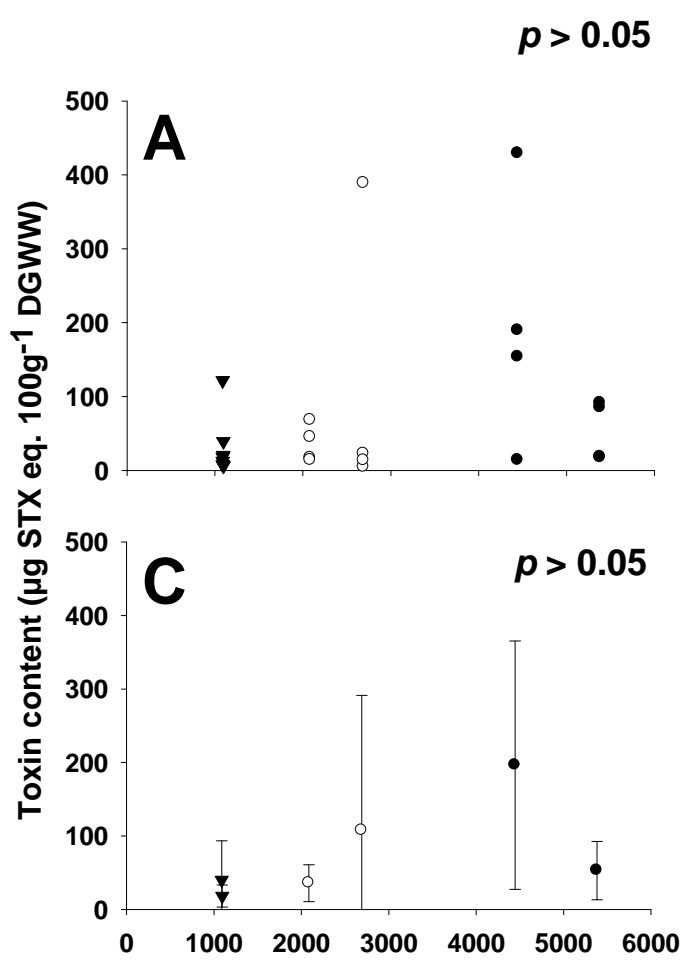

A. minutum concentration (cells. $\mathrm{ml}^{-1}$ )
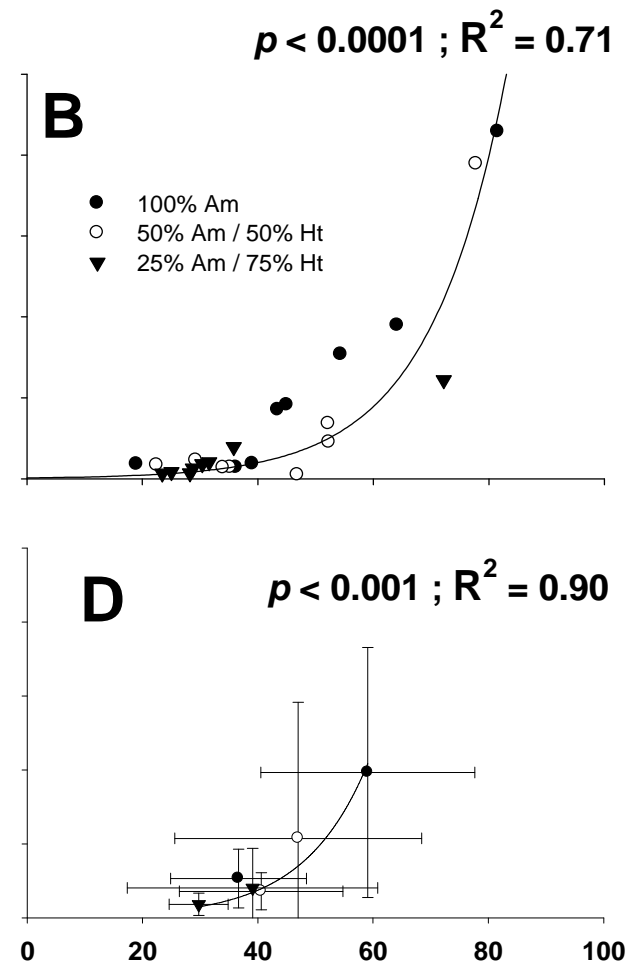

Exposure opening duration (\%)

Figure 4 

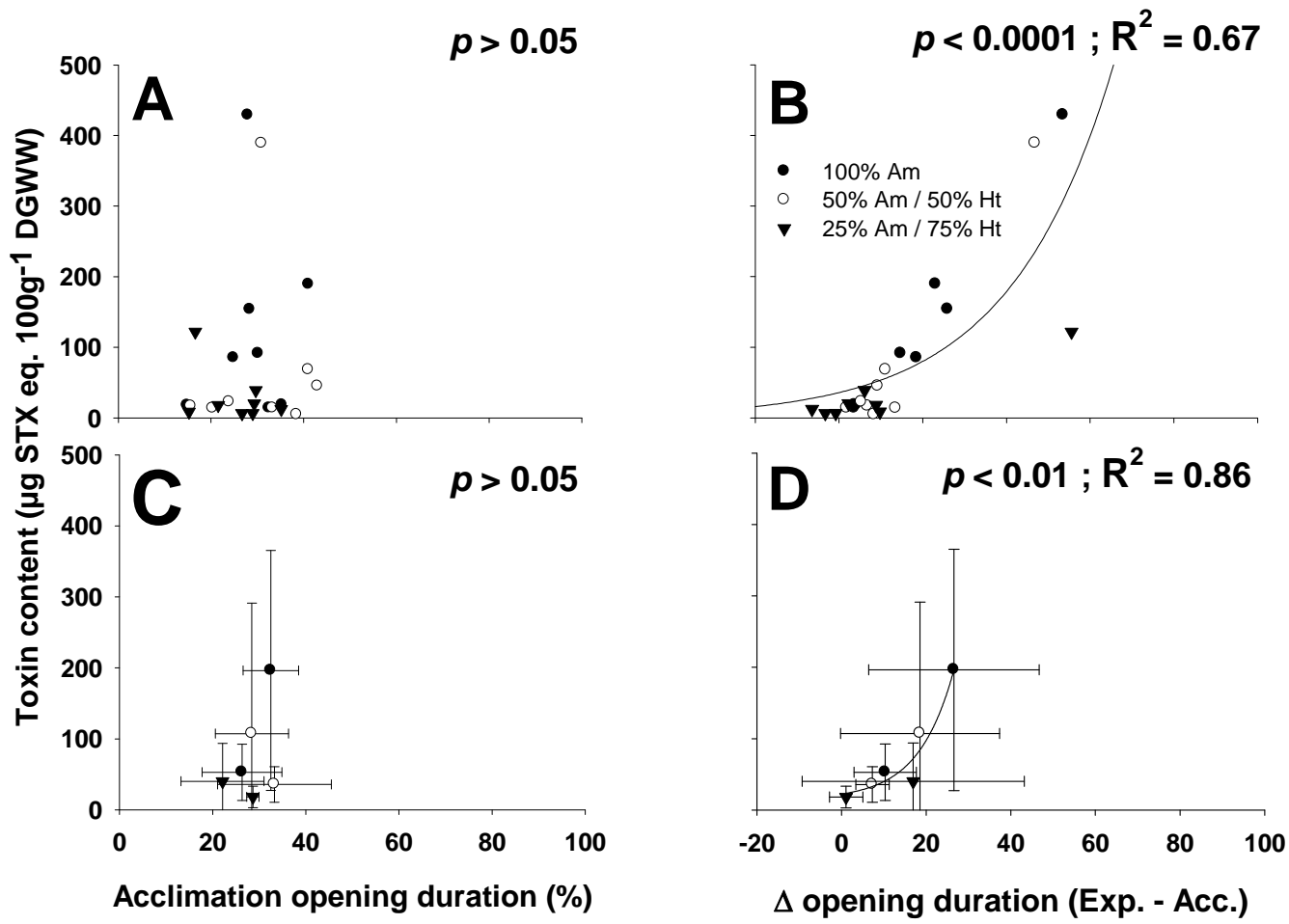

Figure 5 